\title{
GAMBARAN PENGELOLAAN PENYIMPANAN OBAT DI GUDANG FARMASI RUMAH SAKIT PERTAMINA CIREBON
}

\section{THE DESCRIPTION OF DRUG STORAGE IN THE PHARMACY INSTALLATION WAREHOUSE OF PERTAMINA CIREBON HOSPITAL}

\author{
Arsyad Bachtiar, Indah Setyaningsih, Nur Rahmi Hidayati \\ Sekolah Tinggi Farmasi Muhammadiyah Cirebon \\ Jalan Cideng Indah No 3 Cirebon \\ Email: nurrahmihidayati83@gmail.com
}

Submitted : 30 Januari 2021 Reviewed : 19 Februari 2021 Accepted : 24 Maret 2021

\begin{abstract}
ABSTRAK
Manajemen penyimpanan obat di rumah sakit perlu dikelola secara efisien. Ketidakefisienan penyimpanan obat dapat memicu terjadinya kerusakan obat, adanya obat kadaluarsa, dan terganggunya distribusi obat kepada pasien. Tujuan penelitian ini adalah untuk mengetahui gambaran pengelolaan penyimpanan obat di gudang Instalasi Farmasi Rumas Sakit Pertamina Cirebon. Jenis penelitian adalah penelitian deskriptif dengan metode observasi dan wawancara terhadap beberapa tenaga Kesehatan terkait penyimpanan obat yang meliputi pengaturan tata ruang, cara penyimpanan obat dan pencatatan kartu stok. Data yang diperoleh di analaisis berdasarkan Daftar Tilik Jaminan Mutu (Depkes RI, 2002).

Hasil penelitian menunjukkan bahwa peyimpanan obat di gudang Instalasi Farmasi Rumah Sakit Pertamina Cirebon dalam kategori baik dengan memperoleh persentase untuk penyimpanan obat secara keseluruhan adalah $89.47 \%$ mencakup aspek pengaturan tata ruang $88.24 \%$ kategori baik, cara penyimpanan obat $86.67 \%$ kategori baik, dan pencatatan kartu stok $100 \%$ kategori baik.
\end{abstract}

Kata Kunci: Penyimpanan, Aspek penyimpanan obat, Rumah Sakit Pertamina Cirebon

\begin{abstract}
Management of drug storage in hospitals needs to be managed efficiently. Inefficient storage of drugs can lead to drug damage, drug expiration, and disruption of drug distribution to patients. The purpose of this study was to find out the description of drug storage in the Pharmacy Installation Warehouse of Pertamina Cirebon Hospital in 2019. This type of research was descriptive research with observation and interview method using a drug storage questionnaire which included spatial planning, drug storage and recording of stock cards. The results showed that the drug storage in the Pertamina Cirebon Pharmacy Installation Warehouse was in good category by obtaining a percentage for overall drug storage of $89.47 \%$ covering $88.24 \%$ spatial regulation aspects, good method of storing drugs $86.67 \%$ category good, and recording a $100 \%$ good category stock card. Need for other studies that are able to make a better saving the medicines in the Warehouse of hospital.
\end{abstract}

Keywords: Storage, drug storage aspects, Pertamina Cirebon Hospital.

Penulis Korespondensi :

Nur Rahmi Hidayati

Sekolah Tinggi Farmasi Muhammadiyah Cirebon

Jl.Cideng Indah No. 3 Cirebon

Email : nurrahmihidayati83@gmail.com 


\section{PENDAHULUAN}

Peraturan Menteri Kesehatan Republik Indonesia nomor 72 tahun 2016 meyatakan bahwa standar pelayanan kefarmasian adalah tolak ukur yang dipergunakan sebagai pedoman bagi tenaga kefarmasian dalam menyelenggarakan pelayanan kefarmasian. Pelayanan kefarmasian menjadi suatu pelayanan langsung dan bertanggung jawab kepada pasien yang berkaitan dengan sediaan farmasi dengan maksud mencapai hasil yang pasti untuk meningkatkan mutu kehidupan pasien. Pelayanan kefarmasian menjadi bagian integral dari pelayanan di rumah sakit yang turut berperan dalam menentukan kualitas pelayanan para medik (dokter, perawat, bidan, obat-obatan, alat penunjang kesehatan, dan lain sebagainya) terhadap para pasien rumah sakit. Pada umumnya terdapat lima hal penting dalam melakukan pengelolaan obat di Instalasi Farmasi, di antaranya adalah menyusun perencanaan (planning), pengadaan (procurement), penyaluran (distribution), penyimpanan (retention) dan penggunaan (utilization) obat-obatan. Penyimpanan obat adalah suatu kegiatan menyimpan dan memelihara dengan cara menempatkan obat-obatan yang diterima pada tempat yang dinilai aman dari pencurian serta gangguan dari fisik yang dapat merusak mutu obat dan perbekalan kesehatan (Direktur Jendral Bina Kefarmasian dan Alat Kesehatan, 2010). Menurut penelitian Pusat Penelitian dan Pengembangan Biomedis dan Farmasi tahun 2006, masih terdapat banyak gudang penyimpanan obat di puskesmas dan rumah sakit di Indonesia yang kurang memenuhi persyaratan seperti tidak menggunakan sistem alfabetis dalam penataannya, tidak menggunakan sistem First In First Out (FIFO) atau First Expired First Out (FEFO) dan penggunaan kartu stok yang belum memadai. Pihak pengelolaan obat di Instalasi Farmasi wajib memperhatikan kuantitas dan kualitas obat. Memperhatikan kuantitas obat berarti menjaga ketersediaan stok obat. Caranya dengan rajin mengecek pencatatan kartu stok obat dengan metode FIFO atau FEFO. Sementara memperhatikan kualitas berarti menjaga agar obat digunakan sesuai persyaratan resep dokter dan atau apoteker, mengatur kondisi ruangan dan tempat penyimpanan obat yang layak sesuai persyaratan medik, dan memperhatikan tanggal kadaluarsa obat tersebut.

Penelitian sebelumnya oleh Manurung (2018) yang berjudul Profil penyimpanan obat di gudang Instalasi Farmasi BLUD RSUD dr. Ben Mboi termasuk kategori baik dengan persentase $86,84 \%$, meliputi pengaturan tata ruang memperoleh persentase $82,35 \%$ kategori baik, cara penyimpanan obat memperoleh persentase $86,67 \%$ kategori baik, pencatatan kartu stok memperoleh persentase $100 \%$ kategori baik. Tujuan penelitian ini adalah untuk mengetahui gambaran pengelolaan penyimpanan obat di gudang Instalasi Farmasi Rumas Sakit Pertamina Cirebon.

\section{METODE PENELITIAN}

\section{Waktu dan Tempat Penelitian}

Penelitian ini dilakukan di gudang Instalasi Farmasi Rumah Sakit Pertamina Cirebon dan waktu penelitian pada bulan September 2020 sampai Agustus 2021.

\section{Jenis Penelitian}

Penelitian yang dilakukan merupakan penelitian yang bersifat deskriptif dengan menggunakan pendekatan kualitatif untuk memperoleh informasi dari tenaga Kesehatan terkait tentang gambaran pengelolaan penyimpanan obat di gudang Instalasi Farmasi Rumah Sakit Pertamina Cirebon.

\section{Subyek penelitian}

Wawancara terhadap tenaga kesehatan yang bekerja di Gudang farmasi dan semua aspek pengelolaan obat di gudang Instalasi Farmasi Rumah Sakit Pertamina Cirebon. 
Sistem penyimpanan obat yang meliputi pengaturan tata ruang, cara penyimpanan obat dan pencatatan kartu stok.

\section{Instrumen Penelitian}

Instrumen penelitian ini adalah pedoman observasi penyimpanan obat, Daftar Tilik Jaminan Mutu (Depkes RI, 2002).

\section{Analisa Data}

Data yang diperoleh kemudian diolah dan dihitung hasilnya dianalisis secara deskriptif dengan menggunakan persentase dan tabel.

\section{HASIL DAN PEMBAHASAN}

Gudang farmasi merupakan salah satu tempat yang penting dalam menjamin ketersediaan obat dengan keadaan yang stabil, aman dan berkualitas. Menurut peraturan menteri kesehatan gudang harus memenuhi standar terkait luas dan perlengakapan yang baik untuk penyimpanan obat, pengaturan penyimpoanan dan adminitrasi atau pencatatan obat yang disimpan. Berdasarkan penelitian di Instalasi Farmasi Rumah Sakit Pertamina Cirebon pengaturan tata ruang berdasarkan Daftar Tilik Jaminan Mutu (Depkes RI, 2002) yang dilakukan oleh peneliti kepada peugas kesehatan. Hasil penelitian pengaturan tata ruang gudang di Farmasi Rumah Sakit Pertamina Cirebon seperti pada tabel 1.

\section{Tabel I. Persentase Pengaturan Tata Ruang di Gudang Instalasi Farmasi Rumah Sakit Pertamina Cirebon}

\begin{tabular}{|c|c|c|c|}
\hline \multirow{2}{*}{ No } & \multirow{2}{*}{ Pertanyaan } & \multicolumn{2}{|c|}{ Temuan } \\
\hline & & $\mathrm{Ya}$ & Tidak \\
\hline 1 & Tersedia lemari / rak penyimpanan & $\sqrt{ }$ & \\
\hline 2 & Telah ada petugas penyimpanan yang di tunjuk & $\sqrt{ }$ & \\
\hline 3 & Tersedia ruang khusus untuk penyimpanan & $\sqrt{ }$ & \\
\hline 4 & Tersedia cukup dalam penerangan & $\sqrt{ }$ & \\
\hline 5 & Tersedia tempat atau alat pengamanan ruangan (teralis) & $\sqrt{ }$ & \\
\hline 6 & $\begin{array}{l}\text { Pintu gudang obat mempunyai kunci pengaman } 2 \text { (dua) buah yang } \\
\text { terpisah satu sama lain }\end{array}$ & $\sqrt{ }$ & \\
\hline 7 & $\begin{array}{l}\text { Tersedia lemari khusus penyimpanan narkotik danpsikotropik } \\
\text { dengan kunci dobel }\end{array}$ & $\sqrt{ }$ & \\
\hline 8 & Jumlah obat yang diterima sesuai kapasitas gudang & & $\sqrt{ }$ \\
\hline 9 & Tersedia lemari pendingin untuk produk tertentu & $\sqrt{ }$ & \\
\hline 10 & Atap gudang obat dalam keadaan baik dan tidak bocor & $\sqrt{ }$ & \\
\hline 11 & Jendela mempunyai tirai dan dipasang gorden & & $\sqrt{ }$ \\
\hline 12 & $\begin{array}{l}\text { Kunci ruangan penyimpanan hanya dipegang oleh petugas dan } \\
\text { kepala instalasi farmasi }\end{array}$ & $\sqrt{ }$ & \\
\hline 13 & Ada prosedur penyimpanan atau pemisahan & $\sqrt{ }$ & \\
\hline 14 & Gudang obat terpisah dari kamar obat & $\sqrt{ }$ & \\
\hline 15 & $\begin{array}{l}\text { Gudang obat selalu dalam keadaan terkunci apabila tidak ada } \\
\text { aktifitas didalamnya }\end{array}$ & $\sqrt{ }$ & \\
\hline 16 & $\begin{array}{l}\text { Gudang obat bebas dari tikus dan kecoa serta tidak ada tanda-tanda } \\
\text { yang menunjukkan tikus hidup didalamnya }\end{array}$ & $\sqrt{ }$ & \\
\hline \multirow[t]{3}{*}{17} & $\begin{array}{l}\text { Gudang obat dalam keadaan bersih, rak tidak berdebu, lantai } \\
\text { disapu, tembok dalam keadaan bersih }\end{array}$ & $\sqrt{ }$ & \\
\hline & Jumlah & 15 & 2 \\
\hline & Persentase & $88.24 \%$ & $11.76 \%$ \\
\hline
\end{tabular}


Tabel I menunjukkan bahwa pengaturan tata ruang memenuhi kriteria baik yaitu $88,24 \%$ akan tetapi ada yang belum memenuhi kriteria sebesar 11,76 \%. Kriteria yang belum terpenuhi meliputi jumlah obat yang diterima tidak sesuai kapasitas gudang dikarenakan ukuran gudang yang terlalu sempit dan jumlah obat yang dibutuhkan lebih banyak untuk persediaan stok, jendela tidak mempunyai tirai dengan alasan karena belum ada anggaran. Menurut Kemenkes RI Tahun 2010 tentang Materi Pelatihan Manajemen Kefarmasian Instalasi Kabupaten/Kota pengaturan tata ruang berfungsi untuk mendapatkan kemudahan dalam penyimpanan, penyusunan, pencarian dan pengawasan obat, maka diperlukan pengaturan tata ruang gudang dengan baik. Tabel II. Persentase Pengaturan Cara Penyimpanan Obat di Gudang Instalasi
Farmasi Rumah Sakit Pertamina Cirebon

\begin{tabular}{|c|c|c|c|}
\hline \multirow{2}{*}{ No } & \multirow{2}{*}{ Pertanyaan } & \multicolumn{2}{|c|}{ Temuan } \\
\hline & & $\mathrm{Ya}$ & Tidak \\
\hline 1 & Ada catatan obat rusak /expire date & $\sqrt{ }$ & \\
\hline 2 & Tersedia kartu stok dan buku penerimaan & $\sqrt{ }$ & \\
\hline 3 & Ada prosedur rotasi untuk obat antibiotik/produk lainnya & & $\sqrt{ }$ \\
\hline 4 & Pengelompokan dilakukan secara alfabet dan bentuk sediaan & $\sqrt{ }$ & \\
\hline 5 & $\begin{array}{l}\text { Dilakukan pengecekan mutu obat secara organoleptis dan } \\
\text { dicatat dalam buku catatan penyimpanan obat }\end{array}$ & & $\sqrt{ }$ \\
\hline 6 & $\begin{array}{l}\text { Tablet, kapsul dan oralit disimpan dalam kemasan kedap } \\
\text { udara dan disimpan bagian atas rak obat }\end{array}$ & $\sqrt{ }$ & \\
\hline 7 & Cairan, salep dan injeksi disimpan dibagian tengah rak & $\sqrt{ }$ & \\
\hline 8 & $\begin{array}{l}\text { Obat yang membutuhkan suhu dingin disimpan dalam lemari } \\
\text { pendingin }\end{array}$ & $\sqrt{ }$ & \\
\hline 9 & Lemari pendingin ada dalam kondisi baik & $\sqrt{ }$ & \\
\hline 10 & Dalam rak penyimpanan tidak boleh ada obat kadaluarsa & $\sqrt{ }$ & \\
\hline 11 & $\begin{array}{l}\text { Obat dengan masa kedaluarsa lebih pendek disimpan lebih } \\
\text { depan dibandingkan dengan obat yang mempunyai } \\
\text { masa kedaluarsa lebih panjang (First Expire First Out) }\end{array}$ & $\sqrt{ }$ & \\
\hline 12 & $\begin{array}{l}\text { Untuk obat yang tidak mempunyai masa kedaluarsa } \\
\text { penyimpanan berdasarkan kedatanganya. Yang lebih dahulu } \\
\text { datang disimpan disimpan lebih depan dibandingkan } \\
\text { dengan yang datang belakangan (First In First Out) }\end{array}$ & $\sqrt{ }$ & \\
\hline 13 & $\begin{array}{l}\text { Obat yang mempunyai masa kedaluarsa yang sama } \\
\text { digunakan lebih dahulu masuk (First In First Out) }\end{array}$ & $\sqrt{ }$ & \\
\hline 14 & $\begin{array}{l}\text { Tidak ada stok berlebih atau obat yang tidak pernah } \\
\text { digunakan disimpan dalam rak }\end{array}$ & $\sqrt{ }$ & \\
\hline 15 & $\begin{array}{l}\text { Terseda catatan pemusnahan mutasi obat terdiri dari tanggal, } \\
\text { waktu dan cara pemusnahan }\end{array}$ & $\sqrt{ }$ & \\
\hline & Jumlah & 13 & 2 \\
\hline & Persentase & $86.67 \%$ & $13.33 \%$ \\
\hline
\end{tabular}

Tabel II menunjukkan bahwa penyimpanan obat di Gudang Instalasi Farmasi Rumah Sakit Pertamina Cirebon memenuhi kriteria baik yaitu 86,67\%, tetapi ada yang belum memenuhi kriteria sebesar 13,33\% yakni, tidak ada prosedur rotasi untuk obat antibiotik/ produk lainnya dikarenakan belum dibuatnya SOP, tidak dilakukan pengecekan mutu obat secara organoleptis dan dicatat dalam buku catatan penyimpanan obat karena SDM belum tercukupi untuk menjalankan kegiatan tersebut dikarenakan pertimbangan biaya yang harus dikeluarkan. Cara penyimpanan obat merupakan salah satu faktor yang sangat diperlukan untuk menjamin obat sehingga mempermudah distribusi serta pelayanan obat. 


\section{Tabel III Persentase Pengaturan Pencatatan Kartu Stok di Gudang Instalasi Farmasi Rumah Sakit Pertamina Cirebon}

\begin{tabular}{|c|c|c|c|}
\hline \multirow{2}{*}{ No } & \multirow{2}{*}{ Pertanyaan } & \multicolumn{2}{|c|}{ Temuan } \\
\hline & & $\mathrm{Ya}$ & Tidak \\
\hline 1 & Ada kartu stok untuk tiap item obat & $\sqrt{ }$ & \\
\hline 2 & $\begin{array}{l}\text { Semua informasi yang tertulis pada kartu stok ada yang terbaru } \\
\text { dan benar }\end{array}$ & $\sqrt{ }$ & \\
\hline 3 & $\begin{array}{l}\text { Kartu stok disimpan dan digantung dekat pada masing-masing } \\
\text { item obat yang tersimpan pada rak }\end{array}$ & $\sqrt{ }$ & \\
\hline 4 & Informasi mutasi obat dicatat pada saat transaksi & $\sqrt{ }$ & \\
\hline 5 & Terdapat perhitungan yang akurat pada kolom persediaan obat & $\sqrt{ }$ & \\
\hline 6 & $\begin{array}{l}\text { Pencatatan fisik barang dilakukan secara periodik misalnya } \\
\text { sebulan sekali }\end{array}$ & $\sqrt{ }$ & \\
\hline & Jumlah & 6 & \\
\hline & Persentase & $100 \%$ & \\
\hline
\end{tabular}

Tabel III menunjukkan bahwa pencatatan kartu stok memenuhi kriteria baik $100 \%$. Kartu stok selalu berada disamping jenis obat dan penyusunan kartu stok dipisahkan menurut jenis persediaan dan alfabet, data pada kartu stok digunakan untuk menyusun laporan, perencanaan, pengadaan, distribusi obat dan setiap terjadi mutasi obat dicatat pada saat transaksi, semua informasi yang tertulis pada kartu stok ada yang terbaru dan benar. Kartu stok yang terdapat digudang Instalasi Farmasi Rumah Sakit Pertamina Cirebon menjadi sumber data untuk membuat laporan. Pencatatan kartu stok dilakukan dengan cara mencatat mutasi obat selama penyimpanan sehingga obat dapat dengan mudah dikontrol. Data pada kartu stok digunakan untuk menyusun laporan, perencanaan, pengadaaan, distribusi dan sebagai pembanding terhadap keadaan fisik obat dalam tempat penyimpanan.

\section{Tabel IV. Persentase Penyimpanan Obat di Gudang Instalasi Farmasi Rumah Sakit Pertamina Cirebon}

\begin{tabular}{|c|c|c|c|c|c|c|}
\hline \multirow{3}{*}{ Aspek Penilaian } & \multirow{3}{*}{$\begin{array}{c}\text { Jumlah } \\
\text { Pertanyaan }\end{array}$} & \multicolumn{4}{|c|}{ Jawaban } & \multirow{3}{*}{ Kategori } \\
\hline & & \multicolumn{2}{|c|}{$\mathbf{Y a}$} & \multicolumn{2}{|c|}{ Tidak } & \\
\hline & & $\sum$ & $\%$ & $\sum$ & $\%$ & \\
\hline Pengaturan Tata Ruang & 17 & 15 & $88,24 \%$ & 2 & $11,76 \%$ & Baik \\
\hline $\begin{array}{l}\text { Pengaturan Cara } \\
\text { Penyimpanan Obat }\end{array}$ & 15 & 13 & $86,67 \%$ & 2 & $13,33 \%$ & Baik \\
\hline $\begin{array}{l}\text { Pengaturan Pencatatan } \\
\text { Stok }\end{array}$ & 6 & 6 & $100 \%$ & - & - & Baik \\
\hline Total & 38 & 34 & $89,47 \%$ & 4 & $10,53 \%$ & Baik \\
\hline
\end{tabular}

Tabel IV menunjukkan bahwa kesesuaian penyimpanan obat di gudang Instalasi Farmasi Rumah Sakit Pertamina Cirebon memperoleh persentase 89,47 \% kategori baik. Obat disusun secara alfabet, sesuai bentuk sediaan, ada showcase untuk penyimpanan dan alat kesehatan yang membutuhkan penyimpanan khusus, penyusunan obat sistem FIFO - FEFO, tidak ditemukan obat kadaluarsa, setiap barang masuk dicatat pada kartu stok, gudang obat terpisah dari ruangan lain, tidak ada obat yang rusak disimpan dalam rak, kunci gudang dipegang oleh petugas gudang, gudang selalu terkunci apabila tidak ada aktifitas dalam 
gudang,tersedia tempat atau alat pengaman ruangan (teralis), gudang dalam keadaan bersih, tidak ada tanda-tanda adanya kecoa atau tikus, tersedia catatan pemusnahan, mutasi obat yang terdiri dari tanggal, waktu dan cara pemusnahan, sedangkan 10,53 \% tidak memenuhi persyaratan dimana, jendela tidak mempunyai tirai dan tidak dipasang gorden, jumlah obat yang diterima tidak sesuai kapasitas gudang, tidak dilakukan pengecekan mutu obat secara organoleptis, tidak ada prosedur rotasi untuk obat antibiotik/produk lainnya. Berdasarkan penelitian Undur Saulina Manurung (2018), Profil penyimpanan obat di gudang Instalasi Farmasi BLUD RSUD dr. Ben Mboi termasuk kategori baik dengan persentase 86,84\%, meliputi pengaturan tata ruang memperoleh persentase $82,35 \%$ kategori baik, cara penyimpanan obat memperoleh persentase $86,67 \%$ kategori baik, pencatatan kartu stok memperoleh persentase $100 \%$ kategori baik.

\section{KESIMPULAN}

Penyimpanan obat di gudang Instalasi Farmasi Rumah Sakit Pertamina Cirebon meliputi pengaturan tata ruang $88,34 \%$ memenuhi kriteria (kategori baik), cara penyimpanan obat $86,67 \%$ menemuhi kriteria (kategori baik), pencatatan kartu stok $100 \%$ memenuhi kriteria(kategori baik).

\section{DAFTAR PUSTAKA}

Arikunto S, 2013, Prosedur Penelitian Suatu Pendekatan Praktik, Penerbit Rikena Cipta, Jakarta.

Departeman Kesehatan RI, 2002, Daftar Tilik Jaminan Mutu (Quality Assurance) Pelayanan Kefarmasian di Pelayanan Kesehatan Dasar, Jakarta.

Departeman Kesehatan RI, 2004, Keputusan Menteri Kesehatan RI Nomer 1197/Menkes/SK/X/2004 tentang Standar Pelayanan Farmasi di Rumah Sakit , Jakarta.

Departeman Kesehatan RI, 2010, Buku Petunjuk dan Pengelolaan Gudang Penyimpanan, Direktorat Bina Kefarmasian dan Alat Kesehatan, Jakarta.

Departemen Kesehatan RI, 2014, Peraturan Menteri Kesehatan RI Nomer 56 Tahun 2014 tentang Klasifikasi dan Perizinan Rumah Sakit, Kementerian Kesehatan, Jakarta.

Departemen Kesehatan RI, 2016, Peraturan Menteri Kesehatan RI Nomer 72 Tahun 2016 tentang Standar Pelayanan Kefarmasian di Rumah Sakit, Kementerian Kesehatan, Jakarta.

Kemeskes RI, 2010, Pelatihan Manajemen Kefarmasian di Instalasi Farmasi Kabupaten/Kota, Menteri Kesehatan RI, Jakarta.

Manurung, U.S, 2018, Profil penyimpanan obat di gudang Instalasi Farmasi BLUD RSUD dr. Ben Mboi, KTI, Poltekes Kemenkes Kupang, Kupang. 